\title{
THE LEVELS OF FUNCTIONAL-VEGETATIVE HOMEOSTASIS AS CRITERIA FOR MAGNETOTHERAPY EFFICACY
}

\author{
O. V. Yermishev \\ VASYL STUS DONETSK NATIONAL UNIVERSITY, VINNYTSIA, UKRAINE
}

Background. Disorders of autonomic nervous system caused up to $80 \%$ of functional disorders. There is no information about the influence of magnetotherapy (MT) on the indicators of vegetative homeostasis, which disturbance is a cause of functional pathology.

Objectives. The aim of the study is to investigate vegetative rehabilitation trend of MT in various initial conditions of functional-vegetative disorders.

Methods. Functional-vegetative diagnostics method by V.G. Makats was chosen as a method of control of MT impact. The diagnostic complex BIOTEST-12M was a technical tool. 38 children of different age and gender treated in the Department of Physiotherapy of Vinnytsia Regional Children Clinical Hospital in 2016-2017 were involved in the research. The patients were divided into 7 groups according to the levels of functional vegetative homeostasis.

Results. MT had a different effect on vegetative activity as well as systemic and functional dependence, according to the coefficient of functional vegetative homeostasis. The most positive effect was evidenced in a group with a significant parasympathicotonia (group 1). In the group with severe sympathicotonia (group 6) it had negative effect. There were no gender and age-related characteristic features of the influence of MT on the dispersion of vegetative levels.

Conclusions. Rehabilitation expediency requires maintenance of functional vegetative homeostasis at the level of FCP-VB-FCS in conjunction with functional-vegetative diagnostics using the method of V.G. Makats. Magnetotherapy can be recommended to be used only for patients with significant and expressed parasympathicotonia.

KEY WORDS: magnetotherapy; functional-vegetative diagnostics; vegetative homeostasis; vegetative level; vegetative coefficient.

\section{Introduction}

The disorders of autonomic nervous system (ANS) caused $25-80 \%$ of functional disorders of reserves and mechanisms of adaptation to the changing environment, physical and psychosomatic efforts $[1,2]$. Being of integrative importance at the central level, the ANS ensures regulation of vegetative homeostasis, systemic disorders of which determine the pathogenetic basis of functional and somatic diseases $[1,3$, 4]. Their fundamental evaluation goes beyond certain parameters of vegetative regulation, have need of a systematic approach and study of a holistic organism as a multilevel interdependent system $[5,6]$. A significant support for the problem of vegetative pathogenesis is the normalization of vegetative indices in the

Corresponding author: Oleh Yermishev, PhD, associate professor of Department of Plants Physiology and Biochemistry, Biological Faculty, Vasyl Stus Donetsk National University, 21 600-Richchya Str., Vinnytsia, 21000, Ukraine

E-mail: o.yermishev@donnu.edu.ua

Phone number: +380676504433 rehabilitation period. In this case, special attention should be paid to the use of traditional FAZ (functionally active skin zones) [7-9].

Nowadays, according to the WHO recommendations, 'Electro acupuncture diagnostics and reflexotherapy' should become the basis for rehabilitation medicine (the WHO International Council, Yerevan, 19.09.03). Its General Assembly (2014) herewith officially advises the States (the WHO participants) to include these areas into national health programs and draws attention to the development of biophysical methods of controlling the rehabilitation effectiveness of physiotherapeutic and preformed factors $[5,10,11]$. Therefore, much attention should be paid to the recently discovered 'Functional-vegetative system of a human' (FVS) [12], which has proved the biophysical reality of traditional 'acupuncture channels' as well as their direct relation to the vegetative homeostasis and, in addition, requires defining of its place in the classical physiological system $[13,14]$. 
Low-frequency magnetotherapy (MT) is widely used in modern physiotherapeutic practice using the magnetic component of lowfrequency electromagnetic fields [15-17]. MT has an impressively wide range of indications (anti-inflammatory, anti-oedematous, trophic, hypocoagulant, vasoactive, anaesthetic, stimulating reparative processes and immuno-modelling) [18-20]. The official list of absolute and relative official contraindications is, concurrently, also impressive. The attention is drawn to complete absence of information on the influence of MT on the indicators of vegetative homeostasis, the disturbance of which is conditioned by the development of any functional pathology.

The aim of the study is to investigate autonomic rehabilitation of MT at different initial states of functional vegetative disorders.

\section{Methods}

The research is a fragment of the program 'Two-stage system of rehabilitation of vegetative disorders in children living in the zone of ecological (radiation) control of Ukraine' (is being carried out according to the assignment of the Cabinet of Ministers of Ukraine No. 12010/87). 'Functional-vegetative diagnostics' (FVD) by the method of V.G. Makats has been chosen as a method of control of functional and vegetative efficiency of MT [1214]. This method has been admitted to be used in medical practice by the Academic Council of the Ministry of Health of Ukraine and the joint session of the Republican Problem Commissions (RPC) of Paediatrics, Obstetrics and Gynaecology, Quantum Medicine, Haematology and Transfusiology, New Medical Technology and New Diagnostic Tools (Minutes No. 1, 08-01 dated September 11, 1994).

The diagnostic complex BIOTEST-12M is a technical tool of FVD. The latter does not use traditional external power sources and the RPC 'New medical technology and new methods of diagnostics, prevention and rehabilitation' by the Ministry of Health of Ukraine (Minutes No. 5 dated December 25, 1991) has been approved for practical use. Statistical significance of the obtained data was estimated by means of parametric and nonparametric statistics. The analysis of the results was carried out by means of the computer programs 'Search' (developed by the European Centre for Postgraduate Education of the UNAP).

Functional autonomic systems ('acupuncture channels') are based on the international 'acupuncture nomenclature' (IAN) suggested by the WHO (Table 1). The following zones (levels) of functional-vegetative homeostasis are scientifically based on the coefficients of functional-vegetative homeostasis $(k-V)$ [3]: PA-sig ( $k-V$ to 0.75 - a zone of significant parasympathetic activity); PA-exp (k 0,76-0,86-a zone of expressed parasympathetic activity); FCP ( $k-V$ 0,87-0,94 - a functional compensation zone of parasympathicotonia); VB (k-V 0,951,05 - a zone of vegetative balance); FcS ( $\mathrm{k}-\mathrm{V}$ 1,06-1,14 - a zone of functional compensation of sympathicotonia); SA-exp (k-V 1,14-1,26-a zone of clear sympathetic activity); SA-sig. $(k-V \geq 1,26-a$ zone of significant sympathetic activity). The planned research activities were conducted under the guidance of a high-level expert of the National Academy of Sciences of Ukraine, Doctor Habilitatus in Medicine, Professor V.G. Makats.

38 children (7-16 years old, 13 females and 25 males) were involved in the study; they underwent treatment at the Department of Physiotherapy of the Vinnytsia Regional Children Clinical Hospital in 2016-2017. The children were divided into 7 groups according to the levels of functional vegetative homeostasis: the $1^{\text {st }}$ group - with significant parasympathetic activity (PA-sig); the $2^{\text {nd }}$ - with expressed parasympathetic activity (PA-exp); the $3^{\text {rd }}$ - with the zone of admissible functional vegetative norm (ZAN); the $4^{\text {th }}$ - with expressed sympathetic activity (SA-exp); the $5^{\text {th }}$ - with a significant sympathetic activity (SA-sig). They were also divided into 2 groups according to gender: a female group (FG) - 13 children and

Table 1. Functional autonomic systems 'acupuncture channels' (based on the international 'acupuncture nomenclature' (IAN) suggested by the WHO)

\begin{tabular}{|l|c|c|c|}
\hline \multicolumn{1}{|c|}{ Traditional Channel } & MAH & Traditional Channel & MAH \\
\hline Lungs & LU & Bladder & BL \\
\hline Large Intestine & LI & Kidneys & KI \\
\hline Stomach & ST & Pericardium & PC \\
\hline Spleen, Pancreas & SP & Triple heater & TE \\
\hline Heart & HT & Gallbladder & GB \\
\hline Small intestine & SI & Liver & LR \\
\hline
\end{tabular}


a male one (MG) - 25 children. FVD was twice held in the first half of the day (10:00-12:00) before and after the MT session. The bioelectric activity of 12 symmetrical pairs of functionally active skin zones (24 FAZs) was studied, 2016 tests were carried out. The attention was paid to the direction of dispersion of integral vegetative homeostasis levels. The following areas of influence were chosen for MT: parasternal, epigastric and anterior abdominal wall, intrascapular, lumbar-sacral regions and the region of pelvic (femoral), knee and ankle joints.

\section{Results}

The study of the influence of MT on vegetative activity as well as systemic and functional dependence in the initial significant parasympathicotonia (group 1) proved that, regardless of the topography of the effect, MT positively affects the vegetative homeostasis transforming its vegetative coefficients to a higher level of functional activity at the functional compensation zone of parasympathicotonia (FCP), as evidenced by the increase of functional-vegetative homeostasis coefficient (k-V) from 0.66 to 0.88 (Fig. 1, Table 2).

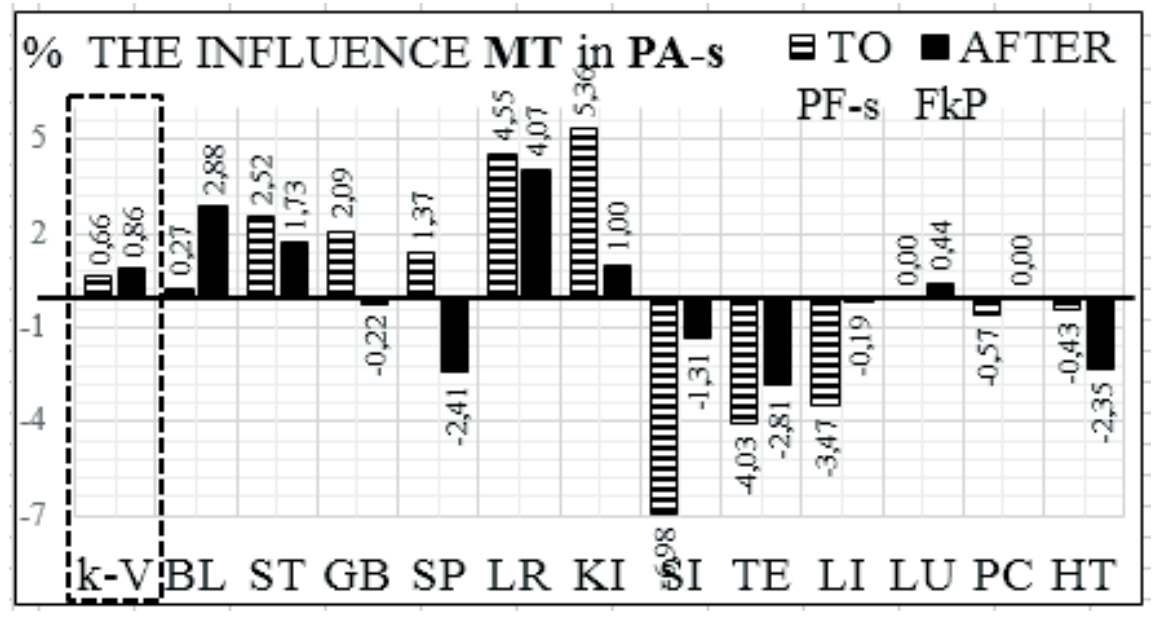

Fig. 1. The influence of MT at PA-sig.

Table 2. The effect of MT on systemic-functional dependence

\begin{tabular}{|c|c|c|c|c|c|c|c|c|c|c|c|c|c|}
\hline MT & k-V & LU & PC & HT & SI & TE & LI & SP & LR & KI & $\mathbf{B L}$ & GB & ST \\
\hline \multicolumn{14}{|c|}{ Initial significant parasympathicotonia (group 1) } \\
\hline 1 * & 0.66 & 8.7 & 7 & 7 & 3.8 & 2.8 & 3.8 & 12 & 12 & 13 & 11.1 & 8.4 & 9.8 \\
\hline $2 *$ & 0.88 & 8.7 & 7.7 & 5.1 & 8.2 & 2.6 & 5.1 & 8.2 & 12 & 12 & 14.1 & 7.2 & 10.2 \\
\hline \multicolumn{14}{|c|}{ Initial expressed parasympathicotonia (group 2) } \\
\hline 1 & 0.85 & 11.2 & 9.4 & 10.2 & 12.6 & 2.7 & 8.3 & 8.8 & 8.6 & 6.7 & 9.4 & 5.3 & 7.8 \\
\hline 2 & 0.90 & 8.0 & 8.4 & 10.5 & 8.8 & 6.3 & 4.2 & 8.0 & 11.3 & 6.3 & 9.2 & 10.5 & 8.4 \\
\hline \multicolumn{14}{|c|}{ Initial functional compensation of parasympathicotonia (group 3) } \\
\hline 1 & 0.90 & 7.4 & 9.7 & 9.5 & 11.4 & 5.9 & 6.7 & 8.6 & 9.0 & 8.0 & 9.9 & 7.6 & 5.9 \\
\hline 2 & 1.25 & 6.8 & 6.5 & 6.8 & 13.5 & 9.5 & 7.2 & 9.0 & 7.2 & 9.0 & 11.3 & 7.9 & 7.2 \\
\hline \multicolumn{14}{|c|}{ Initial autonomic balance of VNS (group 4) } \\
\hline 1 & 1.06 & 11.0 & 9.3 & 8.2 & 11.4 & 3.0 & 7.6 & 11.0 & 4.0 & 4.9 & 18.3 & 5.3 & 5.5 \\
\hline 2 & 0.86 & 6.7 & 8.3 & 8.8 & 10.2 & 5.4 & 10.0 & 14.0 & 8.0 & 7.9 & 10.6 & 4.8 & 5.4 \\
\hline \multicolumn{14}{|c|}{ Initial functional compensation of sympathicotonia (group 5) } \\
\hline 1 & 1.07 & 7.5 & 7.2 & 8.7 & 13.7 & 5.0 & 8.0 & 8.7 & 7.5 & 8.6 & 10.1 & 7.2 & 7.7 \\
\hline 2 & 0.86 & 7.5 & 9.2 & 9.6 & 11.7 & 4.7 & 4.9 & 10.0 & 8.2 & 9.6 & 9.2 & 7.0 & 8.8 \\
\hline \multicolumn{14}{|c|}{ Initial significant and expressed sympathicotonia (groups 6,7) } \\
\hline 1 & 1.26 & 8.8 & 6.3 & 5.7 & 9.1 & 10.0 & 11.0 & 7.1 & 8.5 & 8.0 & 8.8 & 6.0 & 11.1 \\
\hline 2 & 2.28 & 4.6 & 6.8 & 3.0 & 6.1 & 10.6 & 11.0 & 9.5 & 2.7 & 3.8 & 31.6 & 3.8 & 6.1 \\
\hline
\end{tabular}

Notes: 1 * - here and further. Before the exposure of magnetic radiation.

$2 *$ - here and further. After the exposure of magnetic radiation. 
The study of the influence of MT on vegetative activity and systemic-functional dependence in the initial expressed parasympathicotonia (group 2) revealed that, regardless of the topography of the effect, MT affects the vegetative homeostasis relatively positively, translating its vegetative coefficients to higher levels of functional activity, as proved by the increase of the coefficient of functional vegetative homeostasis (kV) from 0.85 to 0.9 (Fig. 2, Table 2).

What is more, the dispersion of the levels of vegetative balance (LVB) under the influence of MT was present, which was accompanied by the transition of $28.57 \%$ of children to the FCP zone and $14.28 \%$ to the zone of VB and FCS (Table 3).
The system correlation of 'acupuncture channels LU-PC-HT, SI-TE-LI, ST-GB-KI-LR) was in a state of interrelated dynamic functional compensation (Fig. 2).

The study of the influence of MT on vegetative activity and systemic an functional dependence taking into account the initial functional compensation of parasympathicotonia (group 3), the initial autonomic balance of VNS (group 4) and the initial functional compensation of sympathicotonia (group 5) proved that the effect of magnetotherapy was relatively neutral concerning functional vegetative homeostasis, which in approximately $70 \%$ of cases fluctuated within the functional compensation of sympathetic and parasympathetic activities (Table 3). The value of ve-

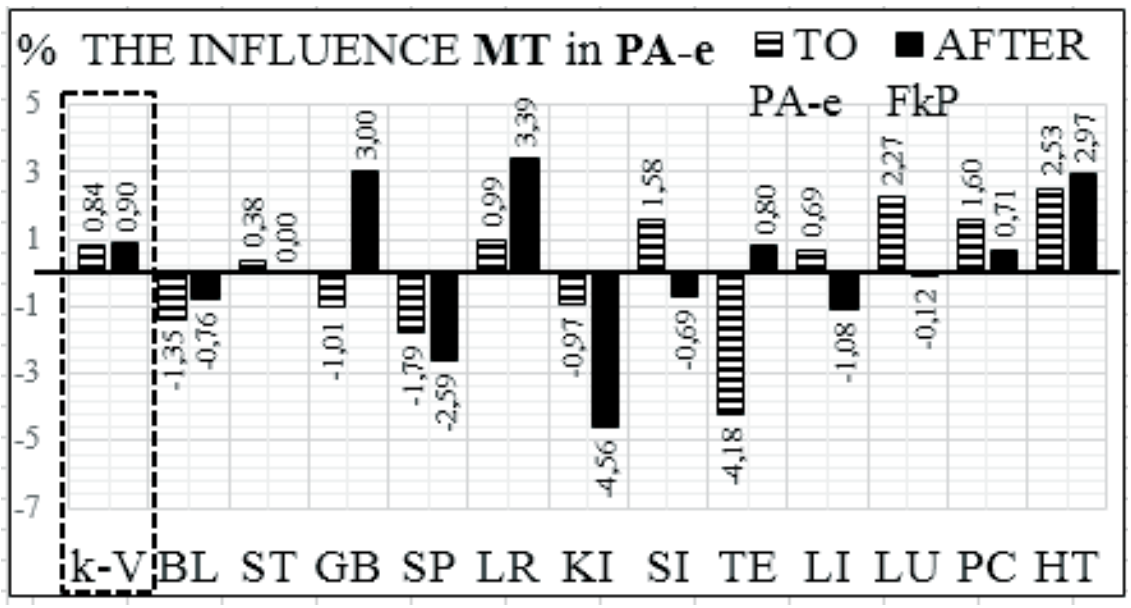

Fig. 2. The influence of MT at PA-exp.

Table 3. The influence of MT on the dispersion of the levels of vegetative balance (LVB), \%

\begin{tabular}{|c|c|c|c|c|c|c|c|}
\hline MT & PA-sig & PA-exp & FCP & VB & FcS & SA-exp & SA-sig \\
\hline \multicolumn{8}{|c|}{ Initial significant parasympathicotonia (group 1) } \\
\hline 1 & 100 & & & & & & \\
\hline 2 & 33.33 & 33.33 & 33.33 & & & & \\
\hline \multicolumn{8}{|c|}{ Initial expressed parasympathicotonia (group 2) } \\
\hline 1 & & 100 & & & & & \\
\hline 2 & 14.28 & 28.57 & 28.57 & 14.28 & 14.28 & & \\
\hline \multicolumn{8}{|c|}{ Initial functional compensation of parasympathicotonia (group 3) } \\
\hline 1 & & & 100 & & & & \\
\hline 2 & & & 37.50 & 25.00 & & 25.00 & 12.50 \\
\hline \multicolumn{8}{|c|}{ Initial autonomic balance of VNS (group 4) } \\
\hline 1 & & & & 100 & & & \\
\hline 2 & 20.00 & & 20.00 & 30.00 & 20.00 & 10.00 & \\
\hline \multicolumn{8}{|c|}{ Initial functional compensation of sympathicotonia (group 5) } \\
\hline 1 & & & & & 100 & & \\
\hline 2 & & 12.50 & 12.50 & 50.00 & 12.50 & & 12.50 \\
\hline \multicolumn{8}{|c|}{ Initial significant and expressed sympathicotonia (groups 6,7) } \\
\hline 1 & & & & & & 100 & \\
\hline 2 & & & & & 25.00 & 50.00 & 25.00 \\
\hline
\end{tabular}


getative coefficients $(k V)$ pointed to the tendency to 'maintain stability' and the systemic ratio of acupuncture channels LU-PCHT, SI-TE-LI, ST-GB-KI-LR, in its turn, was staying in a state of interdependent dynamically functional compensation (Table 2).

The study of the influence of MT on vegetative activity and systemic and functional dependence in the initial expressed and significant sympathicotonia (groups 6-7) revealed that $\mathrm{MT}$, regardless of the topography of the effect, negatively affected the vegetative homeostasis increasing its level of significant neo-rewards (Fig. 3, Table 2), which was accompanied by a significant increase in the value of $\mathrm{kV}$ from 1.26 to 2.28. In case of MT only $25 \%$ were transformed to the poor level of functional activity at the zone of functional compensation of sympathicotonia (FCS) (Table 3). The systemic ratio of acupuncture channels LU-PC-HT, SI-TE-LI, ST-GB-KI-LR), in this case, was in a state of interdependent dynamic functional compensation (Fig. 3).

Investigating the gender and age characteristic features of the influence of MT on the dispersion of the vegetative levels, the same type of dispersion of vegetative levels in the female and male study groups was revealed (Table 3).

The analysis proved that there was no gender and age-related influence of MT on the variance of vegetative levels. Under all conditions, this factor positively affected only the initial levels of the benefits of parasympathetic activity. Its usage in other vegetative disorders caused development of a higher sympathetic orientation. The conclusion was drawn according to the directed dispersion of vegetative levels at various states of initial vegetative disorders (Table 4).

\section{Discussion}

The data on the effect of magnetic radiation on the vegetative status of animals and humans can be found in the literature. The effect of weak (up to $3.5 \mathrm{mT}$ ) and low-frequency (up to $100 \mathrm{~Hz}$ ) impulse magnetic field on the state of vegetative nervous system of animals has been studied by analyzing the variability of heart rate. The effect of magnetic field was evaluated by a individually designed complex for recording cardiac signals of animals. Several specially selected regimes of impulse magnetic fields were studied. It was proved that the impulse magnetic field was of a high biological activity at all regimes used, and the indices of vegetative nervous system after the exposure to impulse magnetic field were about to the values typical for normotonic animals. This made it possible to use magnetic fields at those regimes in magnetotherapy [21].

The study of the effect of transcranial magnetotherapy on 63 people with the $1^{\text {st }}$ degree AG at the age of 38-50 years old proved that after the course of therapy the number of patients with hyper-sympathicotonia decreased from $24(69 \%)$ to $14(40 \%)$ and the number of patients with normal and asympathicotonic vegetative regulation were $39 \%$ and $21 \%$ respectively [22].

The effect of electromagnetic field of ultrahighfrequency range results in the optimization of autonomic balance of the body in the patients with autonomic nervous system disorders was also evidenced. The electromagnetic field (EMF) had sympatholytic, parasympatolytic and tonic action on a person [23].

We still believe that the data obtained from these studies cannot fully characterize the effect of magnetic and wave effect on the body due to the selected methods of vegetative state

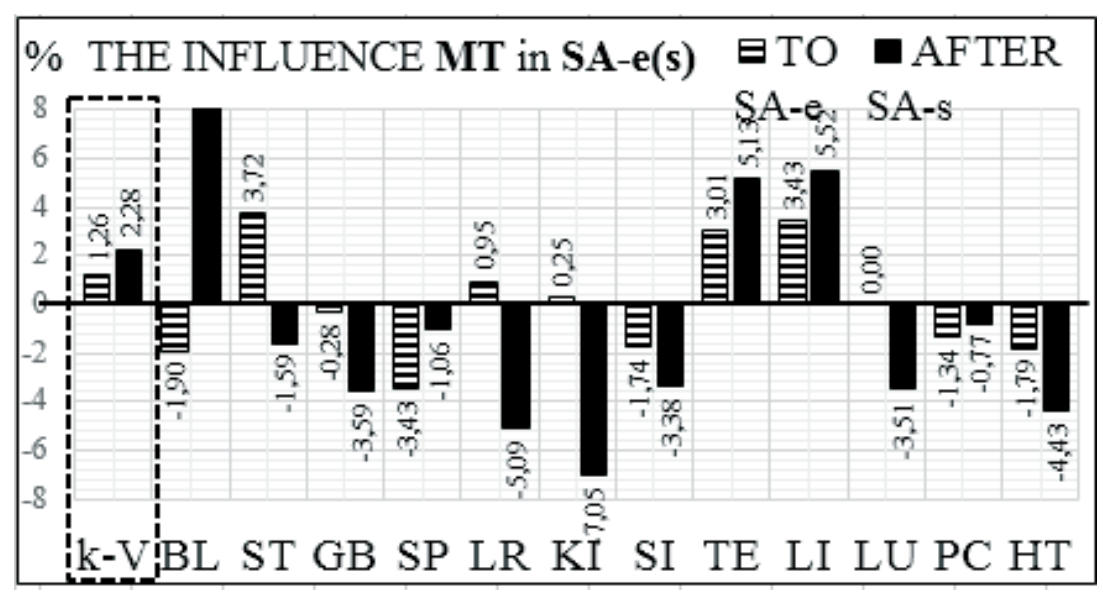

Fig. 3. The influence of MT at initial SA-exp (sig). 
Table 4. The effect of magnetotherapy (MT) on the vegetative dispersion at various stages of initial vegetative disorders in female and male groups

\begin{tabular}{|c|c|c|c|c|c|c|c|c|c|c|c|c|c|c|}
\hline \multirow[b]{2}{*}{ № } & \multicolumn{7}{|c|}{ Female group (in \%) } & \multicolumn{7}{|c|}{ Male group (in \%) } \\
\hline & $\frac{0.0}{n}$ & $\begin{array}{l}\frac{0}{x} \\
0 \\
\frac{1}{2} \\
0\end{array}$ & 岀 & 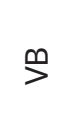 & 岀 & 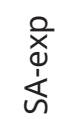 & $\begin{array}{l}\frac{00}{n} \\
\frac{1}{5}\end{array}$ & $\frac{0}{\frac{0}{n}}$ & $\begin{array}{l}\frac{0}{x} \\
0 \\
\frac{1}{\alpha} \\
0\end{array}$ & 嵌 & $\stackrel{m}{>}$ & 氙 & $\begin{array}{l}0 \\
\frac{0}{x} \\
0 \\
\frac{1}{n}\end{array}$ & $\frac{0}{n}$ \\
\hline \multicolumn{15}{|c|}{ Initial significant parasympathicotonia } \\
\hline 1 & 100 & & & & & & & 100 & & & & & & \\
\hline 2 & & & 100 & & & & & & 50 & & 50 & & & \\
\hline \multicolumn{15}{|c|}{ Initial expressed parasympathicotonia (group 2) } \\
\hline 1 & & 100 & & & & & & & 100 & & & & & \\
\hline 2 & & & 100 & & & & & 20 & 20 & 20 & 20 & 20 & & \\
\hline \multicolumn{15}{|c|}{ Initial functional compensation of parasympathicotonia } \\
\hline 1 & & & 100 & & & & & & & 100 & & & & \\
\hline 2 & & & & & & 100 & & & & 42,8 & 42,8 & & & 14,3 \\
\hline \multicolumn{15}{|c|}{ Initial autonomic balance of VNS (group 4) } \\
\hline 1 & & & & 100 & & & & & & & 100 & & & \\
\hline 2 & & & 50 & 25 & 25 & & & 40 & & & 60 & & & \\
\hline \multicolumn{15}{|c|}{ Initial functional compensation of sympathicotonia (group 5) } \\
\hline 1 & & & & & 100 & & & & & & & 100 & & \\
\hline 2 & & & & 66,6 & 16,6 & & 16,6 & & 50 & 50 & & & & \\
\hline \multicolumn{15}{|c|}{ Initial significant and expressed sympathicotonia } \\
\hline 1 & & & & & & 100 & & & & & & & 100 & \\
\hline 2 & & & & & 10 & 60 & 30 & & & & & 25 & 50 & 25 \\
\hline
\end{tabular}

diagnosing. In the first two cases rhythmocardiography was used. Diagnostic tables were used in the third case. These research methods of VNS record the functional state of individual VNS subsystems and separate mechanisms of vegetative regulation. The method of functionalvegetative diagnostics by V.G. Makats provides the results more complete, stable, and comparable in time periods.

Due to the fact that the organism is a multilevel hierarchical system the effect of magnetic fields manifests itself at different levels of organization and depends on many external and internal factors. The reactions of the organism to the action of magnetic fields are characterized by the diversity, instability and phase flow, during which an opposite change is often observed. It is determined by the differences in individual sensitivity of the organism, its systems, and their initial state as well as by the nonspecific character of the action of magnetic fields. The effect of magnetic fields in many cases is normalizing or corrective. To start with, it should be noted that the central parasympatolytic effect during the action of low-frequency magnetotherapy in all groups of observations was revealed. That happens possibly due to the improvement of the parameters of peripheral hemodynamics and sanogenesis processes. This effect, along with the sedative effect of low-frequency magnetotherapy, is realized by affecting the subcortical centres and the pituitary-hypothalamic system. It should also be noted that low-frequency magnetotherapy is capable of exerting an activating influence on the processes of sanogenesis which contributes to restoration of disturbed self-regulation of many functional systems and the organism as a whole. It forms effective protective reactions as well as compensatory and adaptive processes and, moreover, it expands the range of homeostatic response of the organism in conditions of disturbed mechanisms of self-regulation. The obtained data do not coincide with the literature, where the corrective effect of the magnetotherapeutic influence on the parasympathetic and sympathetic units of vegetative NS or pronounced sympatholytic activity is described. This is primarily due to the age characteristic features of the child's organism and its vegetative status. The second important aspect is the method of functional and vegetative diagnosis according to V.G. Makats that was chosen to determine the vegetative status of children, as more universal and complete one. 


\section{Conclusions}

The results of the studies have proved that MT has a different effect on the vegetative activity as well as systemic and functional dependence in the study groups that depends on the coefficient of functional vegetative homeo-stasis. That is, in a group with a significant parasympathicotonia (group 1), MT has a positive effect; in the group with the expressed parasympathicotonia (group 2) it has a relatively positive effect; in the groups with functional compensation of parasympathicotonia (group 3 ), with the autonomic balance of VNS (group 4) and in the group with functional compensation of sympathicotonia (group 5) MT has a relatively neutral effect; in a group with severe sympathicotonia (group 6) it has negative effect and in a group with significant parasympathicotonia (group 7) it has negative effect as well.
According to the results of our research, the absence of gender and age-related influence of MT on the dispersion of vegetative levels has been revealed. Sympathetic vegetative orientation is typical for a low-frequency magnetotherapy in all study groups. Therefore, it can only be used to patients with significant and severe parasympathicotonia.

The rehabilitation expediency requires the maintenance of functional vegetative homeostasis at the level of FcP-VB-FcS in conjunction with functional-vegetative diagnostics using the method of V.G. Makats. The method of functional-vegetative diagnosis is easy to use; it provides repeated comparable results and can be applied in hospital and out-patient environment.

\section{ФУНКЦІОНАЛЬНО-ВЕГЕТАТИВНІ РІВНІ ЯК КРИТЕРІЙ ЕФЕКТИВНОСТІ МАГНITОТЕРАПIї}

ДОНЕЦЬКИЙ НАЦІОНАЛЬНИЙ УНІВЕРСИТЕТ ІМЕНІ ВАСИЛЯ СТУСА, ВІННИЦЯ, УКРАЇНА

\section{O. В. Єрмішев}

Вступ. Близько 80 \% функціональних порушень зумовлено розладами вегетативної нервової системи. На сьогодні немає достатньо даних щодо впливу магнітотерапії (MT) на показники вегетативного гомеостазу при функціональній патології.

Мета дослідження - дослідити тенденції реабілітації при МТ на початкових етапах різних функціональновегетативних розладів.

Методи. Як метод контролю впливу МТ була обрана «Функціонально-вегетативна діагностика» (ФВД) за В. Г. Макацом. Технічним засобом ФВД виступав діагностично-реабілітаційний комплекс БІОТЕСТ-12М. Удослідженні взяли участь 38 дітей різного віку та статі, які проходили лікування у відділенні фізіотерапії Вінницької обласної дитячої клінічної лікарні у 2016-2017 роках. Пачієнтів поділили на 7 груп відповідно до рівнів функціонального вегетативного гомеостазу.

Результати. За коефіцієнтом функціонального вегетативного гомеостазу МТ мала різний вплив як на вегетативну активність, так і на системну, і функціональну залежність. У групі зі значною парасимпатікотонією (група 1) виявлено найбільш позитивний ефект. У групі з вираженою симпатикотонією (група 6) - негативний ефект. Не виявлено гендерних та вікових характерних особливостей впливу МТ на вегетативні рівні.

Висновки. Доцільність здійснення реабілітаційних заходів вимагає підтримки функціонального вегетативного гомеостазу на рівні FCP-VB-FCS у поєднанні з функціонально-вегетативною діагностикою з використанням методу В. Г. Макац. Можна рекомендувати використовувати магнітотерапію лише для хворих зі значно вираженою парасимпатокотонією.

КЛЮЧОВІ СЛОВА: магнітотерапія; функціонально-вегетативна діагностика; вегетативний гомеостаз; вегетативний рівень; вегетативний коефіцієнт.

\section{References}

1. Veyn AM. Vegetative disorders: Clinic, Treatment, Diagnosis. Moscow: MIA; 2000. 752 p.

2. Messina A, Monda M, Valenzano A, Messina G, Villano I, Moscatelli F, Nigro E. Functional Changes Induced by Orexin A and Adiponectin on the Sympathetic/Parasympathetic Balance. Frontiers in Physiology. 2018;9.259:1-6.
3. Chang WH, Lee IH, Chi MH, Lin S-H, Chen KC, Chen PS, Yang YK. Prefrontal cortex modulates the correlations between brain-derived neurotrophic factor level, serotonin, and the autonomic nervous system. Scientific Reports. 2018;8.2558:1-9.

4. Guan L, Collet J-P, Mazowita G, Claydon VE. Autonomic Nervous System and Stress to Predict 
Secondary Ischemic Events after Transient Ischemic Attack or Minor Stroke: Possible Implications of Heart Rate Variability. Frontiers in Neurology. 2018;9.90: $1-16$.

5. Makats VG, Makats EV. Unknown Chinese acupuncture (reality, errors, problems). Vol. I. Vinnytsia: Nilan-LTD ; 2016. 276 p.

6. Makats VG, Makats EV. Unknown Chinese acupuncture (biophysical atlas of systemic dependency). Vol. II . Vinnytsia: Nilan-LTD ; 2016. 204 p.

7. Muzhikov V, Vershinina E, Belenky V, Muzhikov R. Comparative Assessment of the Heart's Functioning by Using the Akabane Test and Classical Methods of Instrumental Examination. Journal of Acupuncture and Meridian Studies. 2017; 10(3): 171179.

8. Vargas-Lunaa FM, Perez-Aldaya EA, HuertaFrancob MR, Delgadillo-Holtforta I. Electric Characterization of Skin Near Biological Active Points and Meridians. International Journal of Bioelectromagnetism. 2010; 12(2): 76-80.

9. Hong $Y$, Shang $H$, Yang $H$, Kong $Q$, Wang $M$, Zhang Q. A 3D recognition and projection system for meridians and acupoints, 2017 IEEE International Conference on Bioinformatics and Biomedicine (BIBM), Kansas City, MO, USA. 2017:1357-1363.

10. Hegyi G, Hamvas S, Havasi M, Petrovics G. Dry Needling Stimulation (Acupuncture) - in Evidence Based Medicine. Austin Journal of Nuclear Medicine and Radiotherapy. 2016;3(2):1-9.

11. Muzhikov V, Vershinina E, Belenky V, Muzhikov R. Comparative Assessment of the Heart's Functioning by Using the Akabane Test and Classical Methods of Instrumental Examination. Journal of Acupuncture and Meridian Studies. 2017;10(3):171-179.

12. Makats VG, Nagaychuk VI, Makats EV, Yermishev OV. Unknown Chinese acupuncture (problems of vegetative pathogenesis). Vol. IV. Vinnytsia: Nilan-LTD ; 2017. 286 p.

13. Makats VG, Nagaychuk VI, Makats EV. Unknown Chinese acupuncture (problems of functional vegetales). Vol. III. Vinnytsia: Nilan-LTD; 2017. 204 p.

14. Makats VG, Nagaychuk VI, Yermishev OV. Fundamentals of Functional Vegetology and
Physiotherapy. Vinnytsia: Nilan-LTD ; 2017. 254 p.

15. Pesqueira T, Costa-Almeida R, Gomes ME. Uncovering the effect of low-frequency static magnetic field on tendon-derived cells: from mechanosensing to tenogenesis. Scientific Reports. 2017; 10948.

16. Cichoń N, Czarny P, Bijak M, Miller E, Śliwiński T, Szemraj J, at al. Benign Effect of Extremely Low-Frequency Electromagnetic Field on Brain Plasticity Assessed by Nitric Oxide Metabolism during Poststroke Rehabilitation. Oxidative Medicine and Cellular Longevity. 2017;2181942,9.

17. Cichoń N, Bijak M, Miller E, SalukJ. Extremely low frequency electromagnetic field (ELF-EMF) reduces oxidative stress and improves functional and psychological status in ischemic stroke patients. Bioelectromagnetics. 2017;38(5):386-396.

18. Yermishev OV, Petruk RV, Ovchynnykova YY, Kostiuk VV. Functional health of children as an ecological bioindicator of Ukraine. Vinnytsia: NilanLTD; 2017. 226 p.

19. Ciejka E, Skibska B, Gorąca A. Influence of low frequency magnetic field used in magnetotherapy on interleukin 6 (IL-6) contents in rat heart and brain. Medycyna Pracy. 2017;68(4):517-523.

20. Pasi F, Sanna S, Paolini A, Alquati $M$, Lascialfari A, Corti ME, et al. Effects of extremely lowfrequency magnetotherapy on proliferation of human dermal fibroblasts. Electromagnetic Biology and Medicine. 2016;35(4):343-352.

21. Kraiukhina K, Lobkaeva EP, Deviatkova NS. Effect of the low-frequency impulse magnetic field on the autonomic nervous system in animals. Biofizika. 2010;55(4): 20-6.

22. Nagornev SN, Frolkov VK, Kulish AV, Gurevich KG, Puzyreva GA, Samsonova OS. The mechanism of realization of hypotensive action of transcranial magnetotherapy in complex treatment of patients with arterial hypertension. Man and his Health. 2017;1:5-11.

23. Sayakhov RF, Kildebekova RN, Mingazova LR, Nizamov AK. The effectiveness of physiotherapeutic effects in the treatment of autonomic nervous system disorders. Fundamental Research. 2010;11:112-114. 